\title{
Pengenalan Wajah Untuk Sistem Kehadiran Menggunakan Metode Eigenface dan Euclidean Distance
}

\author{
(Faces Recognition for Attendance System Using Eigenface and Euclidean Distance \\ Methods)
}

Fahmi Syuhada, I Gede Pasek Suta Wijaya, Fitri Bimantoro

Dept Informatics Engineering, Mataram University

Jl. Majapahit 62, Mataram, Lombok NTB, INDONESIA

Email: fahmisyuhadaa@gmail.com,gpsutawijaya@unram.ac.id,bimo@unram.ac.id

\begin{abstract}
The face as one part of the human body has been widely used as a biometric-based security system. This research is a process of designing and making of the identification system which is able to detect of human attended. This system implements viola-jones, eigenface, and Euclidean distance methods. Viola-jones method is employed as face detection. Eigenface method is employed to reduce the face image via a projection. The Euclidean distance is implemented as a classification method. The accuracy of this system against 30 register subjects and 15 unregistered subjects is $84 \%$. This accuracy is obtained after the addition of face normalization and adaptive training model on the system. Therefore, this research concluded that viola-jones method is very good as face detection, however, need to be added face correction process. Meanwhile, eigenface and Euclidean distance methods provide good results to recognize the face when many training faces are given.
\end{abstract}

Key words: face, recognition, human attended, eigenface, euclidean distance.

\section{I.PENDAHULUAN}

Wajah merupakan salah satu bagian dari tubuh manusia yang memiliki keunikan. Setiap orang di dunia ini memiliki kontur wajah yang berbeda-beda. Oleh sebab itu wajah digunakan oleh semua orang untuk menjadi penanda identitas dirinya agar dapat dikenali oleh orang lain.

Pada era modern ini dimana teknologi berkembang dengan pesatnya, wajah digunakan sebagai bagian yang dapat dikenali oleh komputer. Pendeteksian wajah dan pengenalan wajah merupakan teknik yang digunakan untuk melakukan proses pengenalan wajah pada komputer.

Saat ini sudah terdapat teknologi yang digunakan untuk mendeteksi kehadiran yaitu teknologi absensi sidik jari dan juga wajah. Melalui teknologi ini seseorang dapat diketahui waktu kehadirannya pada suatu tempat dengan cara melakukan proses absen pada mesin absensi. Pada sistem kehadiran yang memanfaatkan sidik jari, pengguna wajib menyentuh sensor sidik jari pada proses absensi. Namun untuk mesin absensi wajah, pengguna wajib melakukan absensi melalui proses perekam wajah dengan cara berdiri didepan sensor kamera. Sedangkan dalam paper ini permasalahan yang diangkat yaitu bagaimana komputer yang sudah terkoneksi kamera webcam dapat mengenali wajah seseorang walaupun orang tersebut tidak secara langsung melakukan proses absensi. Hal ini dilakukan melalui kamera webcam yang terkoneksi akan melakukan proses perekam dan pengenalan terhadap objek wajah yang dideteksi secara real-time. Kemudian dari hasil pengenalan wajah ini, digunakan untuk memperbaharui status kehadiran seseorang pada suatu tempat atau ruangan. Model pengenalan seperti ini sangat cocok diaplikasi untuk absensi kelas pengajaran.

\section{TINJAUAN PUSTAKA}

Sistem deteksi wajah dan pengenalan wajah telah banyak oleh peneliti sebelumnya[1-8]. Untuk deteksi wajah, metode yang banyak digunakan adalah algoritma Viola-Jones[1][7]. Hal ini dikarenakan sistem deteksi wajah Viola-Jones dapat melakukan proses deteksi dengan akurat dan cepat yaitu sekitar 15 kali lebih cepat dari pendekatan yang sudah ada sebelumnya [1]. Sedangkan untuk pengenalan wajah, metode eigenface dan Euclidean distance banyak digunakan karena bekerja dengan secara sederhana dan cepat[2]. Metode ini pada dasarnya adalah mereduksi citra menjadi vektor ciri dimana vektor ciri memiliki ukuran yang sangat kecil dibandingkan ukuran aslinya, sehingga komputasi yang diperlukan sangat pendek. Pengenalan wajah yang berbasis algoritma eigenface yang diekstraksi melaui principle component analysis (PCA) dilaporkan dapat menghasilkan tingkat akurasi pengenalan wajah sebesar 90.83\%[3]. Melaui PCA yang melibatkan prosedur matematis dapat mentransformasikan beberapa variabel yang memiliki korelasi menjadi kumpulan data yang tidak berkorelasi. Kumpulan data ini yang disebut principal component. Proses ini akan menghasilkan eigen vector yang merupakan kombinasi seluruh variasi fitur yang terdapat dalam seluruh data. Jika objek yang digunakan berupa gambar wajah, eigenvector tersebut sering juga disebut eigenface [5]

Penelitian pengenalan wajah menggunakan metode PCA dan Euclidean Distance lainnya melaporkan bahwa akurasi pengenalan optimumnya sebesar $82 \%$ untuk 95 data training 
dan 45 data uji[1]. Lebih lanjut, penggunaan metode eigenface atau PCA untuk sistem absensi memberikan tingkat akurasi sebesar $90.5 \%$ melalui pengujian fungsional[4,6]. Akan tetapi sistem absensi berbasis pengenalan wajah sangat sensitif terhadap pencahayaan saat perekaman.

Pada penelitian ini, eigenface yang dikombinasikan dengan Euclidean Distance digunakan untuk membangun sistem pengenalan wajah untuk absensi tanpa memerlukan proses absensi secara langsung.

\section{METODE PENELITIAN}

Secara umum skema sistem kehadiran secara umum pada penelitian ini dapat diilustrasikan pada Gambar 1. Sedangkan untuk alur kegiatan penelitian ini dibagi menjadi dua kegiatan utama yaitu seperti yang ditunjukkan pada Gambar 2 dan Gambar 3.

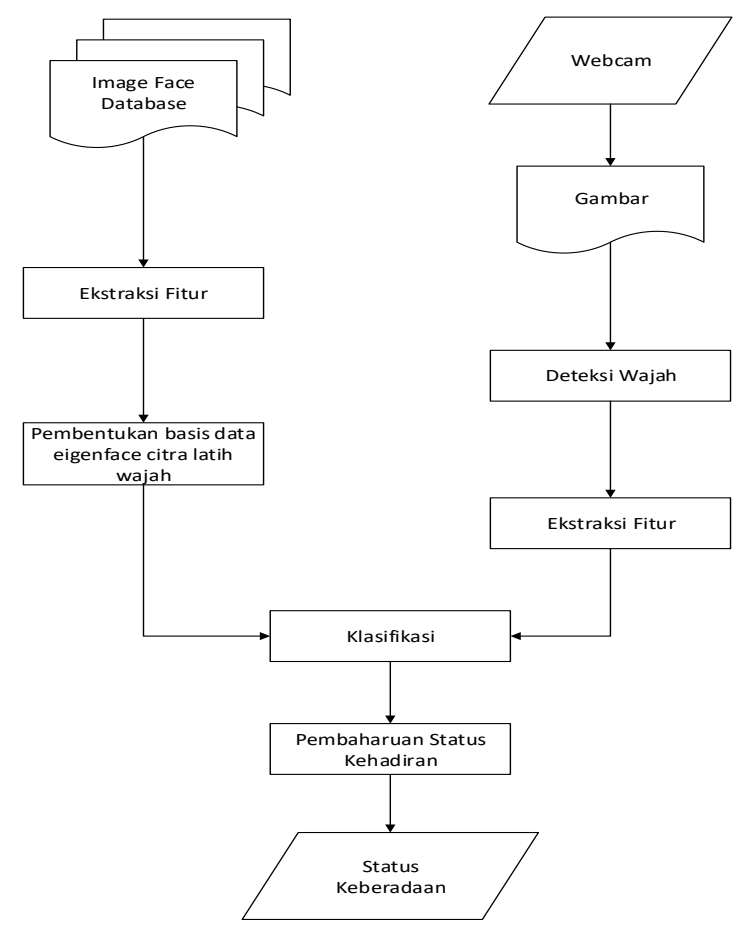

Gambar 1. Blok diagram proses kinerja sistem kehadiran

Pada Kegiatan pertama dilakukan perancangan dan pembangunan sistem agar mampu mendeteksi wajah dari suatu citra masukkan. Setelah dilakukan perancangan dan pembangunan sistem pada kegiatan ini maka akan dilakukan uji coba. Uji coba ini dilakukan untuk melihat seberapa efektif hasil rancangan untuk melakukan deteksi wajah yang sudah dibangun. Jika terjadi kesalahan maka akan dilakukan perbaikan pada kesalahan sistem.

Setelah proses perancangan dan pembangunan sistem deteksi wajah serta pengujian sudah dilakukan, kegiatan selanjutnya yaitu dilakukan pengumpulan data sampel wajah. Data wajah yang dikumpulkan akan disimpan untuk proses pengenalan. Data sampel yang dibutuhkan pada tugas akhir ini adalah sebanyak 30 subjek atau orang dengan model setiap data seorang berbeda-beda. Model-model wajah yang akan dikumpulkan sebagai data sampel pada penelitian ini terbagi menjadi dua yaitu model menghadap lurus kedepan (frontal face) Model kedua yaitu wajah yang lurus menghadap kamera akan tetapi tidak melihat kamera secara langsung. Setiap model wajah terbagi menjadi 5 arah penglihatan yaitu tengah, atas, kanan, bawah, dan kiri.

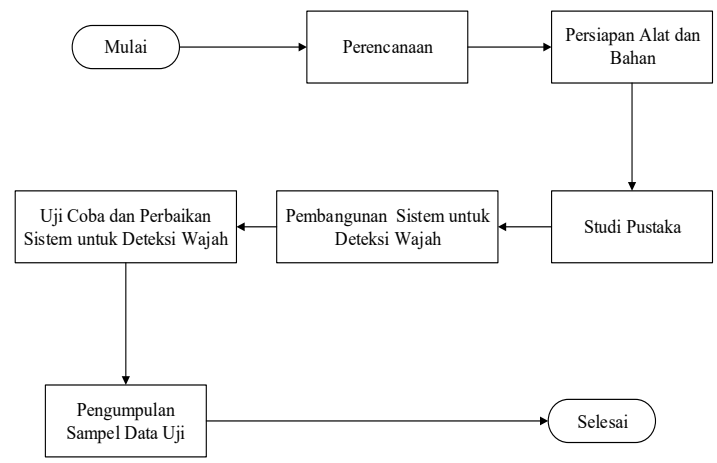

Gambar 2. Diagram alir perancangan dan pembangunan sistem deteksi wajah

Prosedur perancangan dan pembangunan sistem pengenalan ditunjukkan seperti pada Gambar 3. Alur dari jalannya sistem kehadiran dengan pengenalan wajah yang akan dirancang dan dibangun yaitu:

1) Setiap kamera akan menangkap gambar secara terus menerus dengan interval perulangan sebanyak waktu yang akan ditentukan.

2) Setiap hasil tangkapan gambar akan dicek keberadaan wajah menggunakan metode viola-jones.

3) Jika tidak terdapat wajah yang dideteksi maka tidak akan melakukan proses selanjutnya.

4) Jika dideteksi wajah maka akan dilakukan proses perulangan sebanyak jumlah wajah yang berhasil dideteksi untuk dilakukannya proses pengenalan.

5) Pada proses pengenalan langkah awal yang dilakukan adalah melakukan pemotongan terhadap wajah yang dideteksi.

6) Hasil dari perpotongan tersebut yang akan berlanjut ke proses pengenalan.

7) Jika berhasil dikenali maka program akan mengirimkan status IN atau OUT sesuai dengan identitas yang dikenali.

8) Proses ini akan terus berjalan selama program dijalankan.

Secara garis besar penggunaan metode eigenface sebagai ekstraksi fitur dari citra wajah latih ditunjukkan seperti pada Gambar 4. Urutan proses ekstraksi fitur menggunakan metode eigenface, yaitu sebagai berikut:

1) Mengkonversikan citra data latih menjadi vektor citra.

2) Melakukan proses normalisasi terhadap vektor image dengan cara menghitung nilai rata-rata dari image vektor. Setelah didapatkan nilai rata-ratanya, kurangi setiap face vektor dengan nilai mean sehingga diperoleh nilai face vektor ternormalisasi $(A)$. 


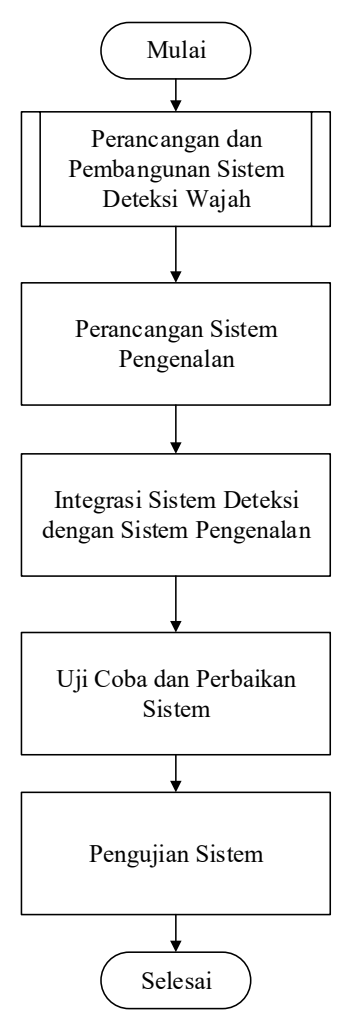

Gambar 3 Diagram perancangan dan pembangunan sistem pengenalan

3) Menghitung matrik kovarian (C) atas face vektor ternormalisasi $(A)$ yaitu $C=$ A.transpose (A).

4) Menghitung nilai eigenvector dari nilai matrik kovarian.

5) Melakukan ekstraksi eigenface dari setiap data latih wajah dengan cara mengalikan hasil normalisasi wajah dan eigenvector yang didapatkan.

Langkah selanjutnya yaitu proses pengenalan wajah yang ditunjukkan pada Gambar 5. Proses pengenalan data wajah baru pada sistem:

1) Proses pertama yaitu preprocessing dimana dilakukan konversi citra wajah dari tipe RGB ke grayscale dan penyekalaan ukuran citra hingga memiliki ukuran citra wajah masukkan sama dengan ukuran citra wajah pelatihan.

2) Citra wajah masukan dikonversikan menjadi vektor citra. Dilakukan proses normalisasi terhadap vektor citra masukan dengan cara yang sama dengan seperti pada proses pelatihan.

3) Ekstraksi data eigenface dari vektor citra masukan ter-normalisasi sehingga didapatkan nilai bobot dari citra yang diperlukan untuk proses pencocokan.

4) Menghitung nilai distance atau jarak antara bobot citra eigenface masukkan dengan bobot citra eigenface hasil pelatihan. Jika didapatkan nilai distance lebih dari threshold yang ditentukan maka citra dianggap tidak dikenali.

5) Jika didapatkan nilai distance kurang dari threshold maka akan dicari nilai distance terkecil untuk menentukan identitas dari wajah masukan.

Pada proses pengenalan wajah diterapkan beberapa proses tambahan yaitu preprocessing yang terdiri atas koreksi area wajah, normalisasi, dan pelatihan adaptive.

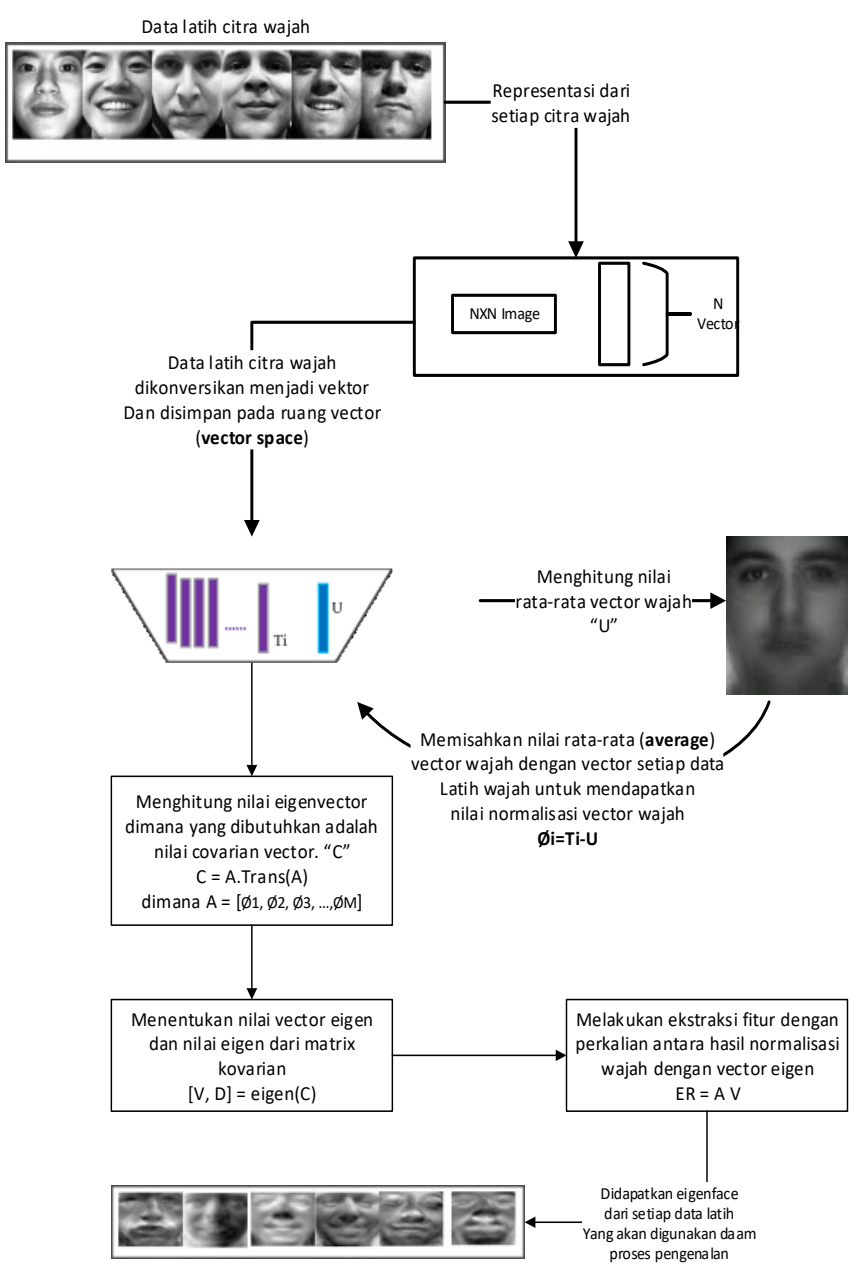

Gambar 4 Skema ekstraksi eigenface

\section{A. Preprocessing}

Pada sistem ini diterapkan beberapa preprocessing. Hal ini dilakukan untuk memperbaiki citra wajah sebelum diproses lebih lanjut pada proses pelatihan maupun proses pengenalan.

\section{A.1. Koreksi area wajah}

Proses koreksi wajah yang dilakukan pada preprocessing merupakan teknik untuk memperbaiki citra wajah yang berhasil dideteksi. Teknik ini digunakan untuk lebih memfokuskan lagi area wajah yang akan digunakan sebagai data latih maupun data uji. 


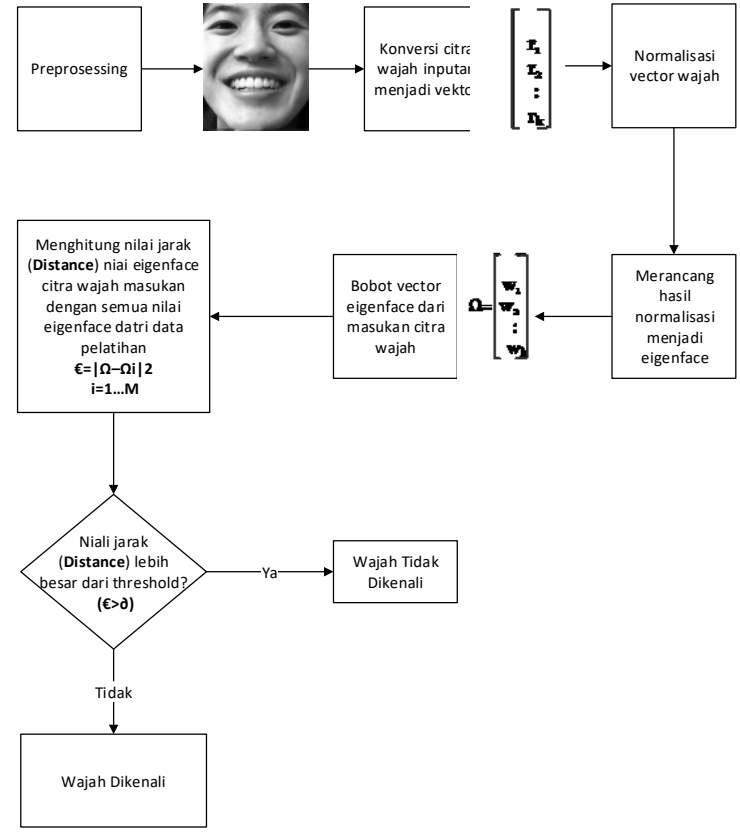

Gambar 5 Algoritma pengenalan wajah

Langkah untuk melakukan teknik ini yaitu pada citra wajah yang sudah didapatkan dilakukan proses deteksi wajah dan mulut. Hasil dari deteksi tersebut akan menghasilkan koordinat yang digunakan untuk membentuk suatu persegi. Dengan koordinat persegi yang didapatkan menjadi nilai parameter untuk melakukan pemotongan gambar. Proses dari koreksi wajah seperti pada Gambar 6.
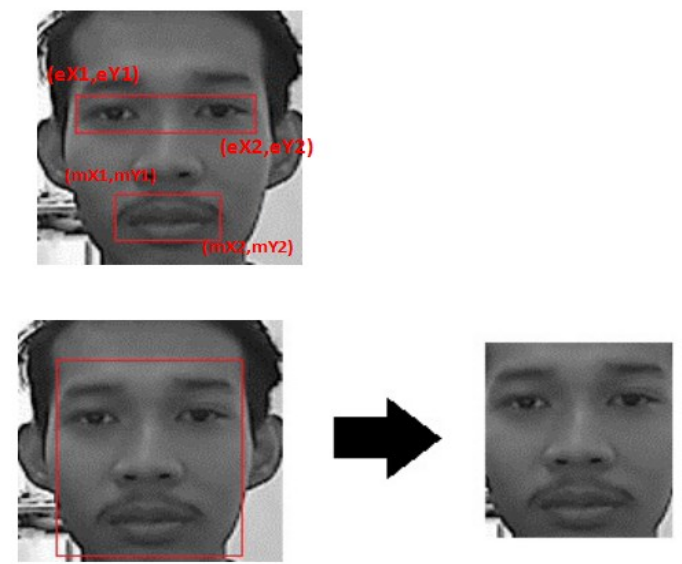

Gambar 6 Proses koreksi wajah

\section{A.2. Normalisasi}

Ketika sudah dilakukan pengambilan data latih dan data uji akan dihasilkan data yang bervariasi. Terkadang muncul variasi data wajah yang terlalu terang dan terlalu gelap. Variasi terang gelapnya citra wajah disebabkan karena parameter pencahayaan ruang diabaikan. Jadinya pada saat dilakukan pengambilan gambar kondisi cahaya cenderung berubah. Hal inilah yang menyebabkan gambar yang diambil terkadang gelap atau cerah. Variasi kontras data yang muncul tersebut akan menjadi faktor yang mempengaruhi akurasi pada saat proses pengenalan.

Pada sistem ini digunakan teknik histogram equalization untuk melakukan normalisasi variasi derajat keabuan pada dua citra wajah atau lebih. Normalisasi dengan teknik ini membuat derajat keabuan pada setiap data citra wajah dibuat rata. Perbandingan histogram citra wajah sebelum dan sesudah mengalami normalisasi disajikan pada Gambar 7 dan Gambar 8.

Pada sistem sudah diterapkan normalisasi untuk mengurangi variasi pencahayaan data yang muncul pada saat preprocessing. Akan tetapi teknik yang digunakan tidak secara penuh mengurangi variasi pencahayaan ini. Untuk mengatasi permasalahan ini, pada sistem diterapkan suatu teknik pelatihan dalam hal ini dinamakan Adaptif Learning. Teknik adaptif learning yang diterapkan pada sistem ini merupakan teknik pelatihan lanjutan yang dilakukan secara terus menurus.

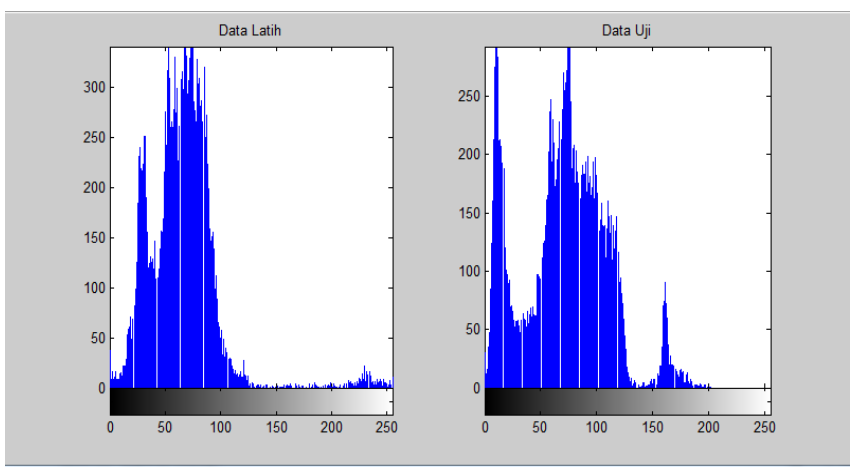

Gambar 7 Histogram citra wajah sebelum normalisasi

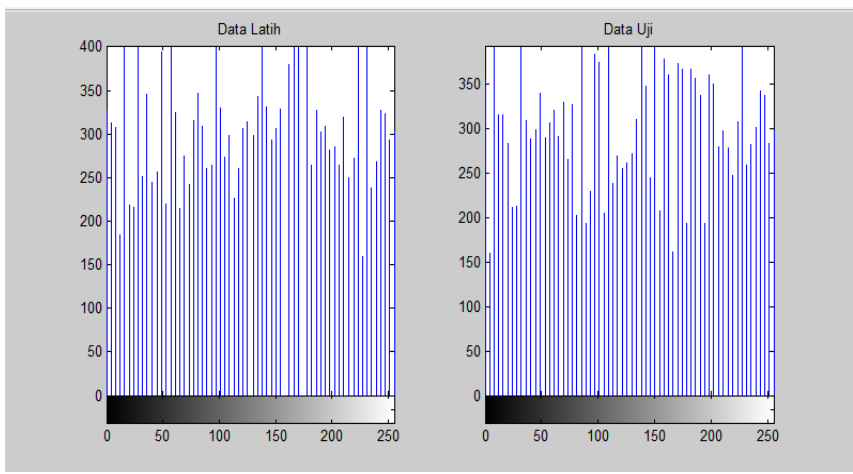

Gambar 8 Histogram citra wajah sesudah normalisasi

\section{B. Pelatihan Adaptif}

Pada saat uji coba simulasi sistem terhadap setiap subjek didapatkan data-data subjek yang berhasil dikenali dan gagal dikenali. Pelatihan lanjutan atau pelatihan adaptif (adaptive learning) berfokus pada data-data wajah yang gagal dikenali. Data wajah yang tidak dikenali akan dimasukkan ke database wajah sesuai dengan identitas subjek data tersebut. Setelah itu sistem akan dilatih kembali. Dari proses pelatihan lanjutan ini sistem dapat mengenali wajah subjek secara baik walaupun terdapat subjek dengan skenario tertentu masih belum dapat dikenali. 


\section{Skenario Pengujian}

Tingkah laku subjek pada saat proses pemasukan data wajah pada sistem kehadiran akan diuji untuk dua kondisi. Kondisi pertama yaitu subjek pengujian pada saat masuk atau keluar ruangan akan diam terlebih dulu sambil menghadap kamera selama beberapa detik sampai data wajahnya dideteksi dan diverifikasi oleh sistem. Kondisi yang kedua yaitu subjek pengujian pada saat masuk atau keluar ruangan tidak ada jeda terlebih dahulu. Artinya subjek langsung berjalan melewati kamera tanpa berhenti menghadap kamera.

\section{HASIL DAN PEMBAHASAN}

\section{A. Data Pengujian}

Data uji yang digunakan untuk proses pengujian sistem terbagi atas dua macam yaitu data subjek terdaftar dan data subjek tidak terdaftar. Data subjek terdaftar digunakan untuk melihat kemampuan sistem untuk dapat mengenali identitas citra wajah masukkan, sedangkan data subjek tidak terdaftar digunakan untuk melihat kemampuan sistem untuk tidak mengenali identitas citra wajah masukkan.

Citra wajah yang didapatkan sebagai data uji berasal dari hasil pengambilan wajah subjek uji. Jumlah subjek terdaftar yang diambil yaitu sebanyak 30 subjek. Sedangkan untuk jumlah subjek yang tidak terdaftar sistem yaitu sebanyak 15 subjek. Setiap subjek memiliki 7 buah data wajah yang sesuai dengan jumlah skenario yang diujikan.

\section{B. Hasil Pengujian Sistem}

Pengujian dilakukan untuk mengetahui tingkat akurasi dari sistem yang dibangun. Terdapat tiga skenario pengujian yang dilakukan yaitu pengujian untuk pengaruh teknik pelatihan, pengujian untuk mengetahui pengaruh koreksi wajah, dan pengujian untuk mengetahui pengaruh prose normalisasi.

Pengujian pertama dilakukan untuk mengetahui pengaruh teknik pelatihan adaptif terhadap performa sistem. Hasil pengujian menunjukkan bahwa pelatihan ini memberikan kontribusi yang signifikan pada peningkatan akurasi pengenalan wajah dari sebesar $40 \%$ menjadi $84 \%$ seperti yang ditunjukkan pada Gambar 9. Hasil ini diperoleh karena dengan pelatihan adaptif setiap sampel wajah diberikan data pelatihan yang lebih banyak dan bervariasi, sehingga setiap objek wajah direpresentasikan oleh banyak eigenface. Hal ini sangat sejalan dengan konsep mesin cerdas bahwa semakin banyak data pelatihan yang diberikan maka semakin cerdas suatu sistem yang diberikan.

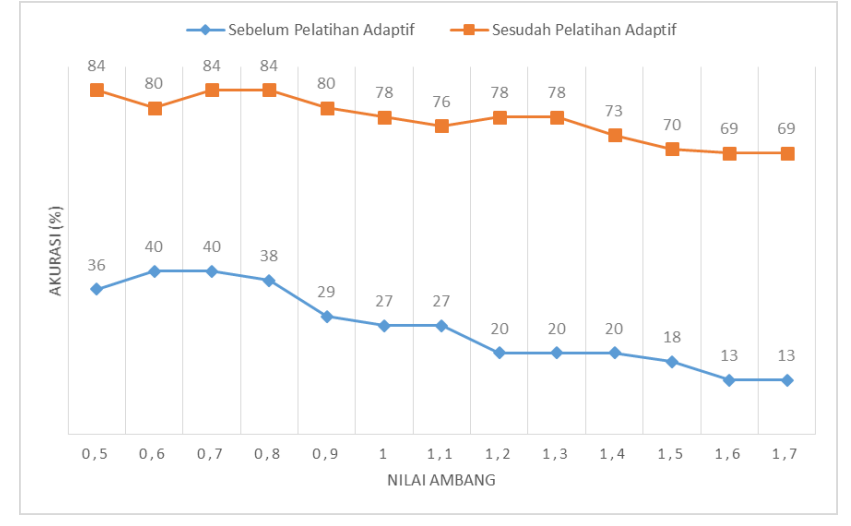

Gambar 9 Pengaruh pelatihan adaptif terhadap akurasi pengenalan

Pada pengujian kedua dilakukan untuk mengetahui pengaruh koreksi wajah terhadap akurasi pengenalan. Pada pengujian kedua ini, hasil pengujian sebelumnya yaitu nilai ambang terbaik $(0,8)$ dan pelatihan adaptif digunakan pengujian ini. Hasil pengujian menunjukkan bahwa penambahan koreksi wajah dapat meningkatkan akurasi pengenalan dari $64 \%$ menjadi $84 \%$ seperti yang ditunjukkan oleh Gambar 10. Hasil ini menggambarkan bahwa koreksi wajah yang berfungsi membuang bagian-bagian wajah yang

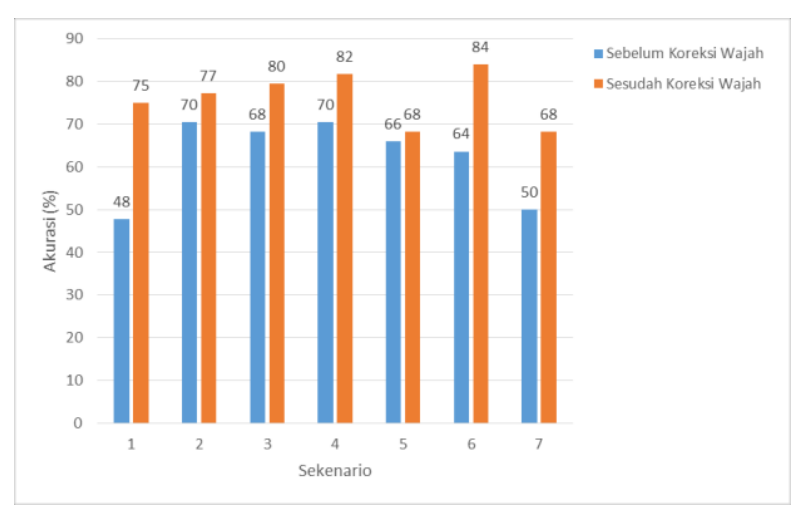

Gambar 10 Pengaruh koreksi wajah terhadap akurasi pengenalan

memiliki variasi yang tinggi seperti gaya rambut, penutup rambut terbukti dapat meningkatkan performansi sistem pengenalan wajah.

Pengujian terakhir dilakukan untuk mengetahui seberapa besar pengaruh proses normalisasi terhadap akurasi pengenalan. Normalisasi pada data wajah dilakukan dengan teknik histogram equalization. Hasil pengujian (lihat Gambar 11) menunjukkan ternyata normalisasi sangat mempengaruhi performansi pengenalan. Hal ini mengindikasikan bahwa normalisasi yang diterapkan mampu mengurangi variasi wajah akibat variasi pencahayaan saat perekaman wajah. 


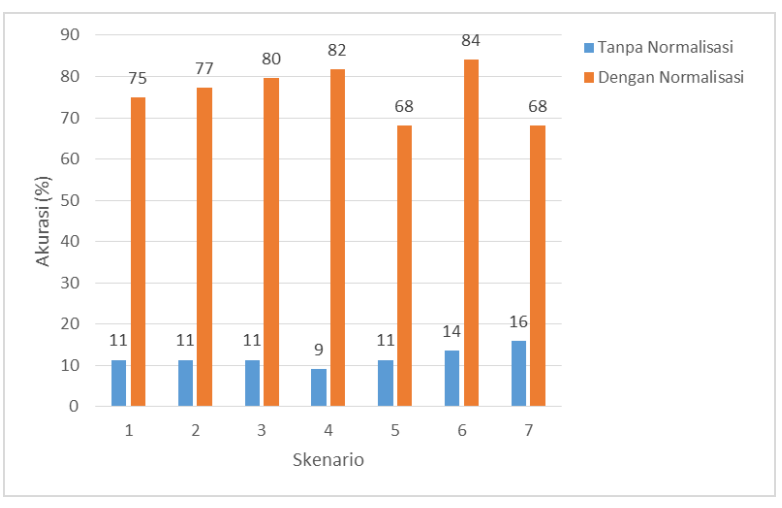

Gambar 11 Pengaruh normalisasi terhadap akurasi pengenalan

Hasil pengujian ini mengkonfirmasi bahwa metode eigenface baik digunakan untuk mereprentasikan ciri wajah sebagaimana teorinya[5] yang menyatakan bahwa wajah dapat diwakilkan oleh sebagian kecil komponen principal-nya yang dinyatakan oleh eigenvectors yang memiliki nilai eigen values terbesar.

\section{KESIMPULAN DAN SARAN}

Berdasarkan hasil pengujian dan analisanya dapat disimpulkan beberapa hal yaitu:

a) Tingkat akurasi tertinggi yang didapatkan dari sistem usulan dengan pelatihan adaptif yaitu sebesar $84 \%$.

b) Preprocessing sangat mempengaruhi tingkat akurasi sistem dengan selisih $20 \%$ untuk penambahan koreksi wajah dengan nilai ambang terbaik0.8.

c) Preprocessing dengan normalisasi histogram equalization meningkatkan akurasi sebesar 70 $\%$.

d) Metode Eigenface dan Euclidean Distance baik digunakan untuk melakukan pengenalan wajah jika banyak variasi data yang dimiliki degan kata lain semakin banyak variasi data yang dimiliki semakin akurat hasil pengenalannya.
Sistem usulan ini masih perlu pengembangan untuk meningkatkan performanya, yaitu:

a) Sistem ini perlu menerapkan beberapa proses preprocessing untuk setiap data wajah. Masih banyak proses preprocessing yang dapat diuji-cobakan untuk dapat meningkatkan nilai akurasi sistem.

b) Sistem ini belum diuji-cobakan pada jenis kamera yang memiliki resolusi lebih dari 2 MP. Untuk pengembangan selanjutnya dapat dilakukan pengujian untuk kamera yang memiliki tingkat resolusi yang lebih tinggi.

c) Pengujian terhadap sistem dilakukan pada satu tempat saja. Untuk pengembangan bisa dilakukan pengujian untuk tempat yang berbeda.

\section{DAFTAR PUSTAKA}

[1] P. Viola, dan M. Jones. "Rapid object detection using a boosted cascade of simple features," in the 2001 IEEE Computer Society Conference, vol. 1, 2001.

[2] S. Wasista, Sistem Pengenalan Wajah Pada Mesin Mahasiswa Menggunakan Metode PCA dan DTW. ITS, Surabaya, 2011.

[3] A. Saefullah., Aplikasi Face Recognition Menggunakan Metode Eigen Face dan Principal Component Analysis. 2015.

[4] A. Putra, Perancangan dan Pengembangan Sistem Absensi Real-time Melalui Metode Pengenalan Wajah. Singaraja: Universitas Pendidikan Ganesha, 2014.

[5] M.T. Pentland. "Face Recognition Using Eigenface," in Proceedings of IEEE Conf. on Computer Vision and Pattern Recognition, pp 586-591, 1991.

[6] M. Turk dan A. Pentland, "Eigenfaces for recognition," Journal of Cognitive Neuroscience, vol. 3, no. 1, pp. 71-86, 2001.

[7] I. G. P. S. Wijaya, I. B. K. Widiartha, dan K. Uchimura, "Decreasing false positive detection of Haar-Like based face detection using skin color filtering for crowded face images," in Proceedings of the 15th Seminar on Intelligent Technology and Its Applications (SITIA 2014), Surabaya Indonesia, 2014.

[8] W. Chen, J. E. Meng, dan S. Wu, "PCA and LDA in DCT domain," Pattern Recognition Letter, vol. 26, pp. 2474-2482, 2005. 